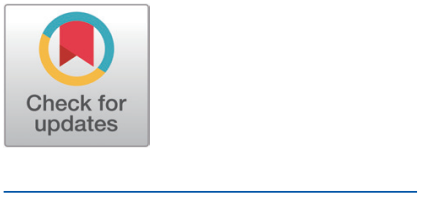

Received: Sep 10, 2020

Revised: Oct 15, 2020

Accepted: Oct 23, 2020

*Corresponding author Jong Geun Kim

Graduate School of International Agricultural Technology, Seoul National University, Pyeongchang 25354, Korea. Tel: +82-33-339-5728

E-mail: forage@snu.ac.kr

Copyright $\odot 2021$ Korean Society of Animal Sciences and Technology.

This is an Open Access article distributed under the terms of the Creative Commons Attribution Non-Commercial License (http:// creativecommons.org/licenses/by$\mathrm{nc} / 4.0 /$ ) which permits unrestricted non-commercial use, distribution, and reproduction in any medium, provided the original work is properly cited.

ORCID

Sheng Nan Wei

https://orcid.org/0000-0001-5117-5140 Yan Fen Li

https://orcid.org/0000-0002-7318-7318

Eun Chan Jeong

https://orcid.org/0000-0002-6559-2743 Hak Jin Kim

https://orcid.org/0000-0002-7279-9021

Jong Geun Kim

https://orcid.org/0000-0003-4720-1849

Competing interests

No potential conflict of interest relevant to this article was reported.

Funding sources

This work was carried out with the support of "Cooperative Research

Program for Agriculture Science

\section{Effects of formic acid and lactic acid bacteria inoculant on main summer crop silages in Korea}

\author{
Sheng Nan Wei ${ }^{1}$, Yan Fen $\mathrm{Li}^{1}$, Eun Chan Jeong ${ }^{1}$, Hak Jin Kim ${ }^{2}$ and \\ Jong Geun Kim ${ }^{1,2 *}$ \\ ${ }^{1}$ Graduate School of International Agricultural Technology, Seoul National University, Pyeongchang \\ 25354, Korea \\ ${ }^{2}$ Research Institute of Eco-friendly Livestock Science, GBST, Seoul National University, Pyeongchang \\ 25354, Korea
}

\section{Abstract}

To improve the fermentation quality of silage and reduce the nutrients loss of raw materials during the ensiling process, silage additives are widely used. The effect of additives on silage is also affected by the species of crop. Therefore, this study was designed to explore the effects of formic acid (FA) and lactic acid bacterial inoculant on the quality of main summer crop silage. The experiment was consisted on split-plot design with three replications. The experiment used the main summer forage crops of proso millet ("Geumsilchal"), silage corn ("Gwangpyeongok"), and a sorghum-sudangrass hybrid ("Turbo-gold"). Treatments included silage with Lactic acid bacterial Inoculant (Lactobacillus plantarum [LP], $1.0 \times 10^{6} \mathrm{CFU} / \mathrm{g}$ fresh matter), with $\mathrm{FA}(98 \%, 5 \mathrm{~mL} / \mathrm{kg}$ ), and a control (C, without additive). All silages were stored for 60 days after preparation. All additives significantly increased the crude protein content and in vitro dry matter digestibility (IVDMD) of the silages and also reduced the content of ammonia nitrogen $\left(\mathrm{NH}_{3}-\mathrm{N}\right)$ and $\mathrm{pH}$. Corn had the highest content of IVDMD, total digestible nutrients and relative feed value among silages. Compared with the control, irrespective of whether FA or LP was added, the water soluble carbohydrate (WSC) of three crops was largely preserved and the WSC content in the proso millet treated with FA was the highest. The treatment of LP significantly increased the lactic acid content of the all silage, while the use of FA significantly increased the content of acetic acid $(p<0.05)$. The highest count of lactic acid bacteria (LAB) was detected in the LP treatment of corn. In all FA treatment groups, the total microorganism and mold numbers were significantly lower than those of the control and LP groups $(p<0.05)$. In conclusion, both additives improved the fermentation quality and nutritional composition of the main summer forage crops. The application of FA effectively inhibited the fermentation of the three crops, whereas LAB promoted fermentation. So, both FA and LP can improve the quality of various species of silage.

Keywords: Corn, Sorghum-sudangrass hybrid, Proso millet, Additives, Silage 
and Technology Development (Project No. PJ01401903)" Rural Development Administration, Republic of Korea.

Acknowledgements Not applicable.

Availability of data and material Upon reasonable request, the datasets of this study can be available from the corresponding author.

Authors' contributions

Conceptualization: Wei SN, Kim JG.

Data curation: Wei SN, Kim JG.

Formal analysis: Li YF, Jeong EC, Kim HJ.

Methodology: Wei SN, Li YF, Jeong EC, Kim HJ.

Software: Li YF, Jeong EC.

Validation: Kim JG.

Investigation: Li YF, Kim HJ.

Writing - original draft: Wei SN, Kim, JG

Writing - review \& editing: Wei SN, Kim, JG.

Ethics approval and consent to participate This article does not require IRB/IACUC approval because there are no human and animal participants.

\section{INTRODUCTION}

At present, silage corn (Zea may L.) and sorghum-sudangrass hybrids (Sorghum bicolor $\times$ S. bicolor L., SSH) continue to be the main summer crops used as feed resources in many countries. Corn is a widely recognized cereal used mainly in food, livestock feed, and industrial raw materials. Corn is also known as the "king of the forages," having a global annual production that exceeds those of wheat and rice. Silage corn is a high-yield crop that effectively uses nutrients in the soil. Among the forage crops, corn is the crop with the highest nutritional yield. It also has excellent productivity and feed value, and, in particular, has high sugar content, good fermentation quality, and high palatability to livestock [1].

SSH have the highest dry matter (DM) yield among various forages. Compared to corn, they have a smaller leaf area, more secondary roots, and a waxier leaf surface, which help them withstand drought better than corn [2]. They also can effectively increase soil organic matter content in areas with good sunlight [3]. In addition to the two aforementioned crops, proso millet (Panicum miliaceium L.) has also attracted attention because of its short planting cycle and strong growth in saline soil. Proso millet is within the genus Panicum and has high drought and salt tolerance and strong resistance to many diseases affecting corn [4]. Corn is the crop with the highest total digestible nutrients (TDN) yield per unit area. SSH is higher in productivity than corn, but has a disadvantage of lower quality. Proso millet has the disadvantage of low quantity, however, it can be used when corn or SSH cannot be sown due to a short growing period. It has a higher content of crude protein $(\mathrm{CP})$ compared to other crops [5].

Progressively more attention has been given to methods that can produce high-quality silage to improve animal production performance. In recent years, to improve the fermentation quality of silage, various additives have been used to promote or inhibit fermentation, reduce fermentation losses, and improve animal performance, and different types of additives have been shown to have different effects on silage. In the fermentation process, microorganisms, especially lactic acid bacteria (LAB), are most critical. Lactic acid, which reduces the $\mathrm{pH}$, is produced by LAB through fermentation. The low $\mathrm{pH}$ limits plant enzymatic activity; therefore, $\mathrm{LAB}$ inoculants are crucial in the production of silage [6]. Use of an inoculant is now the predominant technology employed to influence silage fermentation. Kung and Muck [7] found that homo-fermentative inoculants can improve animal performance by $3 \%$ to $5 \%$. Tao [8] inoculated silage with LAB and showed that the $\mathrm{pH}$ decreased significantly and the quality of the silage obtained was improved in comparison with non-inoculated silage.

Contrary to the promotion of fermentation by LAB, chemical additives such as formic acid can inhibit silage fermentation. Adding formic acid can effectively inhibit fungal and plant enzyme activities in the silage and reduce protein loss [9]. There are reports [10] stating that elephant grass treated with $0.5 \%$ formic acid improved the fermentation, intake, and digestibility compared to an untreated control.

Due to the differing nutritional contents of various forages, the effects of additives also differ. Furthermore, there is little information related to a comparison of the effects of different additives on corn, sorghum-sudangrass hybrids, and proso millet. Therefore, this experiment was designed to explore the effects of different additives on the quality of different crop silages.

\section{MATERIALS AND METHODS}

\section{Silage preparation}

Proso millet (“Geumsilchal"), silage corn (“Gwangpyeongok"), and sorghum-sudangrass hybrid 
("Turbo-gold") were collected after harvest from the experimental field of Seoul National University, Pyeongchang Campus (located at $37^{\circ} 32^{\prime} 40^{\prime \prime} \mathrm{N}, 128^{\circ} 26^{\prime} 33^{\prime \prime} \mathrm{E}$ ), during the summer season of 2019. All crops were chopped into lengths of 2-3 cm using a fodder chopper (Richi Machinery, Henan, China). The chopped crop materials were spread flat on plastic film and sprayed with an equal amount of different additives. The additives included Lactobacillus plantarum $(1.5 \times$ $10^{10} \mathrm{CFU} / \mathrm{g}$ fresh matter, CMbio, Anseong, Korea) and formic acid (98\%, Junsei Chemical, Tokyo, Japan). The silage treatments were as follows: (1) control (distilled water), (2) inoculant LAB (1.0 $\times 10^{6} \mathrm{CFU} / \mathrm{g}$ fresh matter), and (3) formic acid $(5 \mathrm{~mL} / \mathrm{kg})$. Then, the chopped crop materials were ensiled into 20-L mini silos, which were sealed tightly with lids. Three replications were performed for each treatment. The 27 mini silos were preserved at ambient temperature and with a dark and dry environment for 60 days before opening.

\section{Chemical analysis}

Approximately $500-\mathrm{g}$ samples were collected and then dried at $65^{\circ} \mathrm{C}$ in an air-forced drying oven for $72 \mathrm{~h}$ to determine the content of DM. The dried samples were ground to pass through a 1-mm screen (Thomas Scientific, Swedesboro, NJ, USA). CP was measured by the Dumas method, as described by Jean-Baptiste-André Dumas [11], using an Automatic Elemental Analyzer Euro Vector EA3000 (EVISA, Milan, Italy). Acid detergent fiber (ADF) and neutral detergent fiber (NDF) were measured by the method of Van Soest et al. [12] using an $\mathrm{ANKOM}^{2000}$ Automated Fiber Analyzer (Ankom Technologies, Fairport, NY, USA). Heat-stable amylase and sodium sulfite were used for the NDF procedure. Water soluble carbohydrate (WSC) was analyzed by modifying the anthrone method proposed by Yemm and Willis [13]. TDN and RFV were calculated by the formula described by Holland et al. [14]. In vitro dry matter digestibility (IVDMD) is an index used to analyze the nutrient digestibility of feed materials in animals [15]. It was determined by the following procedure. First, $0.5-0.6 \mathrm{~g}$ of ground sample was weighed into filter bags, which were sealed using a heat sealer (\#HS: $100 \mathrm{~V}-120 \mathrm{~V} /$ \#HSi: $220 \mathrm{~V}-240 \mathrm{~V}$ ). The samples were distributed evenly on both sides of Daisy Incubator digestion jars (Ankom Technologies, Fairport, NY, USA). Then, 1,330 mL of buffer solution A and $266 \mathrm{~mL}$ of buffer solution B were added into each jar. Two healthy Holstein steers were selected and cannulated. Their rumen fluid was collected through four layers of cheesecloth before the morning feeding. Then, $400 \mathrm{~mL}$ of rumen fluid was added to the buffer solution and samples. The digestion jar was purged with $\mathrm{CO}_{2}$ gas for $30 \mathrm{~s}$, and the lid was secured. The samples were incubated at $39^{\circ} \mathrm{C}$ for $48 \mathrm{~h}$. Then, the procedure for determining NDF was used to obtain IVDMD.

\section{Microbial analysis and fermentation quality}

The spread-plate method [16] was used for microbial analysis. The samples $(10 \mathrm{~g})$ were diluted with $90 \mathrm{~mL}$ of sterilized saline solution $(8.50 \mathrm{~g} / \mathrm{L} \mathrm{NaCl})$ and shaken for $1 \mathrm{~h}$. Serial dilutions $\left(10^{-1}-10^{-5}\right)$ were streaked on de Man, Rogosa, and Sharpe agar medium, plate count agar medium, and potato dextrose agar medium.

\section{Analysis of fermentation quality}

Ten gram (10 g) of fresh chopped silage sample was weighed into a $250-\mathrm{mL}$ conical flask and covered with $100 \mathrm{~mL}$ of distilled water. The sample was shaken for $1 \mathrm{~h}$ with a shaker (Green Sseriker, Vision Scientific, Daejeon, Korea) and stored in a refrigerator for $24 \mathrm{~h}$, during which time the conical flasks were shaken by hand every $2 \mathrm{~h}$. The mixture was then filtered through filter paper (Whatman No. 6, ADVANTEC, Toyo Roshi Kaisha, Ltd, Japan), and the filtrate was used to measure the $\mathrm{pH}$ of the silage using a $\mathrm{pH}$ meter ( $\mathrm{AB}$ 150, Fisher Scientific International, 
Pittsburgh, PA, USA). Subsequently, $1.5 \mathrm{~mL}$ of the filtrate was used to analyze the contents of organic acids by high performance liquid chromatography (HPLC) using a system (HP-1100, Agilent Technologies, Santa Clara, CA, USA; Column: Agilent Hi-Plex H, $7.7 \times 300$ mm, 8 rm (p / n PL1170-6830), Mobile phase: $0.005 \mathrm{M} \mathrm{H}_{2} \mathrm{SO}_{4}, 0.7 \mathrm{~mL} / \mathrm{min}$, detector: $\mathrm{UV}, 55^{\circ} \mathrm{C}$, Injection volume: $20 \mu \mathrm{L}$ ) equipped with a refractive index detector. Lactic, acetic, and butyric acid were used to assess the quality of the silages according to the Flieg-Zimmer scale [17]. The buffering capacity (BC) was determined following the method described by Playne and McDonaldet [18]. Ammonia nitrogen $\left(\mathrm{NH}_{3}-\mathrm{N}\right)$ was analyzed via the method described by Broderick and Kang [19].

\section{Statistical analysis}

All data were subjected to analysis of variance using the General Line Model (GLM) of SPSS (SPSS 20.0 program, SPSS, Chicago, IL, USA). The completely random design was used for the effect of varieties on chemical composition, pre0ensiling characteristics and bacterial population, and the split plot design was used for the effect of varieties (main plot) and additive treatment (sub plot) on silage. Mean treatment differences were obtained by Duncan's multiple range tests with a level of statistical significance of $5 \%$.

\section{RESULTS}

\section{Characteristics of raw material}

The chemical compositions and characteristics of the raw materials are shown in Table 1. Proso millet had the highest DM and WSC contents. There was no significant difference in CP content among the three crops $(p>0.05)$. The lowest $\mathrm{ADF}$ and NDF contents were detected in corn. These were significantly lower than those of proso millet and sorghum-sudangrass hybrid $(p<0.05)$. The $\mathrm{pH}$ of corn (5.80) was significantly lower than those of proso millet and sorghum-sudangrass hybrid $(p<0.05)$. Furthermore, corn had the lowest BC and the highest LAB and TM (total

Table 1. Chemical composition, pre-ensiling characteristics, organic acids, and bacterial population of raw materials

\begin{tabular}{|c|c|c|c|c|c|}
\hline Parameter & Proso millet & Corn & SSH & SEM & $p$-value \\
\hline \multicolumn{6}{|c|}{ Chemical composition (g/kg DM) } \\
\hline DM & $303.4^{\mathrm{a}}$ & $277.3^{b}$ & $192.8^{c}$ & 23.214 & $<0.0001$ \\
\hline ADF & $326.4^{b}$ & $287.8^{c}$ & $439.9^{a}$ & 28.746 & $<0.0001$ \\
\hline NDF & $607.2^{\mathrm{b}}$ & $530.1^{c}$ & $662.5^{\mathrm{a}}$ & 48.241 & 0.0247 \\
\hline $\mathrm{pH}$ & $6.0^{\mathrm{a}}$ & $5.8^{\mathrm{b}}$ & $6.1^{\mathrm{a}}$ & 0.117 & 0.0013 \\
\hline $\mathrm{NH}_{3}-\mathrm{N} / \mathrm{TN}$ & $29.8^{\mathrm{b}}$ & $34.6^{\mathrm{a}}$ & $14.4^{\mathrm{c}}$ & 1.297 & $<0.0001$ \\
\hline WSC & $170.0^{\mathrm{a}}$ & $144.2^{b}$ & $136.7^{\mathrm{b}}$ & 8.162 & $<0.0001$ \\
\hline BC (mEq kg/DM) & $32.0^{\mathrm{b}}$ & $24.2^{c}$ & $55.5^{\mathrm{a}}$ & 5.507 & $<0.0001$ \\
\hline TM & $7.0^{\mathrm{b}}$ & $7.6^{\mathrm{a}}$ & $6.9^{b}$ & 0.427 & 0.0419 \\
\hline
\end{tabular}

Different lowercase letters in the same row indicate significant differences $(p<0.05)$.

$\mathrm{SSH}$, sorghum-sudangrass hybrid; $\mathrm{DM}$, dry matter; $\mathrm{CP}$, crude protein; $\mathrm{ADF}$, acid detergent fiber; NDF, neutral detergent fiber; IVDMD, in vitro dry matter digestibility; $\mathrm{NH} \mathrm{H}_{3} \mathrm{~N}$, ammonia nitrogen; TN, total nitrogen; WSC, water soluble carbohydrate; BC, buffering capacity; FW, fresh weight; LAB, lactic acid bacteria; TM, total microorganisms. 
microorganism) counts, which were significantly higher $(p<0.05)$.

\section{Chemical composition of silage treated with different additives}

The effects of additives on the chemical composition of silage differed depending on the crop (Table 2). The DM content of SSH was significantly lower than those of corn and proso millet $(p<$ $0.05)$, and there was no significant difference among additive treatments of SSH and proso millet $(p>0.05)$. The DM loss of proso millet was higher than those of corn and SSH, and Lactobacillus plantarum (LP) treatment decreased the DM loss in corn significantly $(p<0.05)$.

Low $\mathrm{CP}$ content was observed in the control groups. However, the $\mathrm{CP}$ content was affected by the treatments and was higher in the LP-treated silage $(p<0.05)$. Among these, the CP content in the LP treatment of proso millet was $5.50 \mathrm{~g} / \mathrm{kg}$ higher than that of the control group, and the values for corn and SSH were 5.10 and $20.40 \mathrm{~g} / \mathrm{kg}$ higher, respectively. Among the three crops, the effects of the different additives on the $\mathrm{CP}$ content of corn were not significant.

For proso millet, the contents of NDF and ADF in the LP treatment were significantly lower than in the control group $(p<0.05)$. SSH treated with additives also showed lower values, but these differences were not significant $(p>0.05)$. LP and formic acid (FA) addition significantly $(p<$ 0.05 ) improved the IVDMD of proso millet silages, but no no differences in IVDMD were found among the corn and SSH silage groups.

The estimated TDN content is related to the ADF content. For proso millet, the lowest TDN content was detected in the control group. However, the TDN content of the control group corn was higher than that of the additive group without significant difference $(p>0.05)$.

\section{Fermentation quality of silage treated with different additives}

Compared with the $\mathrm{pH}$ values of the fresh crops, the $\mathrm{pH}$ values of all silages were significantly lower (Fig. 1). Moreover, the $\mathrm{pH}$ values of the additive-treated groups were significantly lower than those of the control groups $(p<0.05)$. Corn silage showed the lowest $\mathrm{pH}$, and proso millet had the

Table 2. Dry matter content, dry matter loss, and chemical composition of silages with different additives

\begin{tabular}{|c|c|c|c|c|c|c|c|c|c|}
\hline Crop & Treatment & DM (g/kg) & DM loss (g/kg) & $\mathrm{CP}(\mathrm{g} / \mathrm{kg})$ & ADF $(g / k g)$ & NDF $(\mathrm{g} / \mathrm{kg})$ & IVDMD (g/kg) & TDN (\%) & RFV \\
\hline \multirow[t]{4}{*}{ Proso millet } & C & 266.00 & 37.40 & $56.60^{b}$ & $358.90^{a}$ & $624.30^{a}$ & $580.30^{b}$ & $60.55^{c}$ & $91^{\mathrm{c}}$ \\
\hline & FA & 266.60 & 36.80 & $58.20^{\mathrm{ab}}$ & $339.00^{\mathrm{ab}}$ & $620.40^{\mathrm{a}}$ & $639.20^{\mathrm{a}}$ & $62.12^{b}$ & $94^{\mathrm{b}}$ \\
\hline & LP & 273.3 & 30.10 & $62.10^{\mathrm{a}}$ & $319.30^{b}$ & $574.60^{b}$ & $627.80^{\mathrm{ab}}$ & $63.68^{\mathrm{a}}$ & $104^{a}$ \\
\hline & Mean & $268.63^{A}$ & $34.77^{\mathrm{A}}$ & 58.97 & $339.07^{\mathrm{B}}$ & $606.43^{A}$ & $615.77^{\mathrm{B}}$ & 62.12 & $96^{\mathrm{B}}$ \\
\hline \multirow[t]{4}{*}{ Corn } & C & $263.00^{\mathrm{a}}$ & $14.30^{\mathrm{b}}$ & 52.00 & 265.20 & $465.10^{b}$ & 684.60 & 69.28 & $137^{\mathrm{a}}$ \\
\hline & FA & $257.40^{\mathrm{b}}$ & $19.90^{\mathrm{a}}$ & 52.20 & 275.90 & $510.80^{a}$ & 688.40 & 68.53 & $123^{b}$ \\
\hline & LP & $265.70^{\mathrm{a}}$ & $11.60^{b}$ & 57.10 & 268.50 & $467.60^{\mathrm{b}}$ & 716.10 & 69.05 & $135^{\mathrm{a}}$ \\
\hline & Mean & $262.03^{A}$ & $15.27^{\mathrm{B}}$ & 53.77 & $269.87^{c}$ & $481.17^{B}$ & $696.37^{A}$ & 68.95 & $132^{A}$ \\
\hline \multirow[t]{4}{*}{$\mathrm{SSH}$} & C & 175.40 & 17.40 & $46.90^{b}$ & 428.00 & 654.80 & 547.10 & 55.09 & 79 \\
\hline & FA & 186.70 & 6.10 & $49.80^{b}$ & 348.10 & 553.60 & 634.00 & 61.40 & 104 \\
\hline & LP & 180.50 & 12.30 & $67.30^{\mathrm{a}}$ & 388.10 & 617.50 & 612.70 & 58.24 & 88 \\
\hline & Mean & $180.87^{\mathrm{B}}$ & $11.93^{\mathrm{B}}$ & 54.67 & $388.07^{\mathrm{A}}$ & $608.63^{A}$ & $597.93^{\mathrm{B}}$ & 58.24 & $90^{B}$ \\
\hline \multirow[t]{3}{*}{$p$-value } & V & $<0.0001$ & $<0.0001$ & 0.8473 & $<0.0001$ & $<0.0001$ & $<0.0001$ & 6.836 & $<0.0001$ \\
\hline & A & $<0.0001$ & 0.0284 & 0.0308 & 0.5713 & 0.0108 & 0.0218 & 0.0406 & $<0.0001$ \\
\hline & $V \times A$ & $<0.0001$ & 0.7282 & $<0.0001$ & $<0.0001$ & 0.0547 & $<0.0001$ & $<0.0001$ & 0.0806 \\
\hline
\end{tabular}

Different lowercase letters in the same column indicate significant differences among additives $(p<0.05)$ and different uppercase letters in the same column indicate significant differences among crops $(p<0.05)$.

DM, dry matter'; CP, crude protein; ADF, acid detergent fiber; NDF, neutral detergent fiber; IVDMD, in vitro dry matter digestibility; TDN, total digestible nutrients; RFV, relative feed value; C, control; FA, formic acid; LP, Lactobacillus plantarum; SSH, Sorghum-sudangrass hybrid; V, variety; A, additive. 


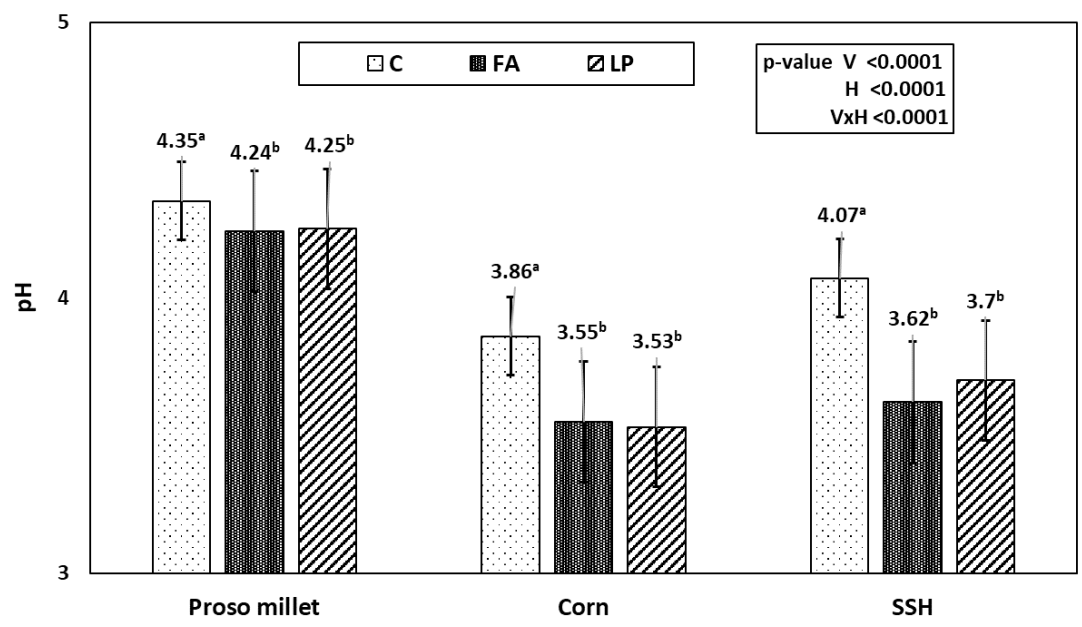

Fig. 1. The pH values of the silages with formic acid (FA) and Lactobacillus plantarum (LP) and of the control $(\mathbf{C})$. Vertical bars represent the standard error of the means $(n=9)$. Means with different letters in the same crop are significant at $p<0.05$.

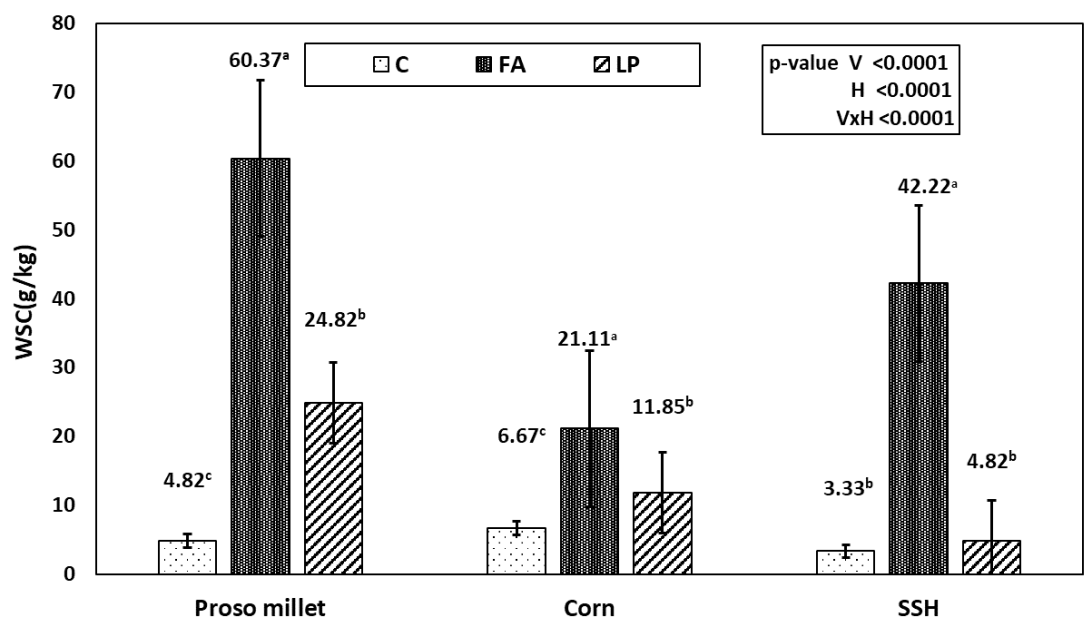

Fig. 2. WSC content of silage with formic acid (FA) and Lactobacillus plantarum (LP) and of the control (C). Vertical bars represent the standard error of the means $(n=9)$. Means with different letters in the same crop are significant at $p<0.05$. WSC, water soluble carbohydrate.

highest.

The WSC concentrations of the silages were higher $(p<0.05)$ in the FA-treated silage than in the control and LP-treated silages, and the residual amounts of WSC were in the order of $\mathrm{C}<\mathrm{LP}$ $<$ FA (Fig. 2). As can be seen from Fig. 3, the $\mathrm{NH}_{3}-\mathrm{N} /$ total nitrogen (TN) contents of the additivetreated groups were much lower than those of the control groups, and proso millet silage had higher $\mathrm{NH}_{3}-\mathrm{N} / \mathrm{TN}$ than the corn and $\mathrm{SSH}$ silages.

\section{Organic acids of silage with different additives}

Table 3 shows the organic acid contents of the additive-treated silages. The additives had significant $(p<0.05)$ effects on the lactic acid and acetic acid contents and the lactic acid/acetic acid ratio (LA/ 


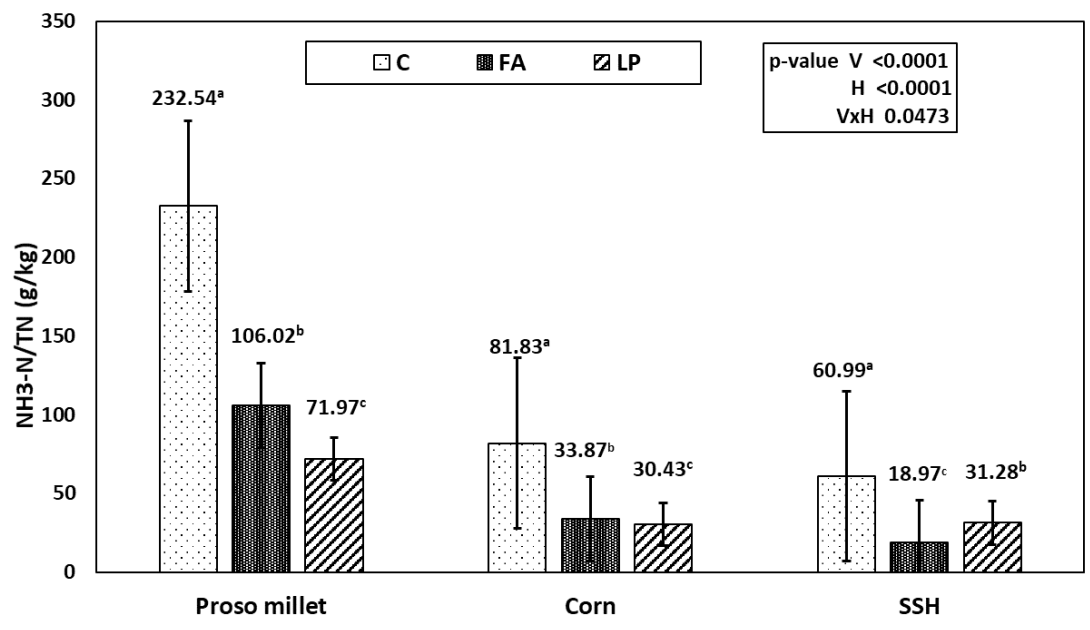

Fig. 3. The $\mathrm{NH}_{3}-\mathrm{N} / \mathrm{TN}$ values of the silages with formic acid (FA) and Lactobacillus plantarum (LP) and of the control $(C)$. Vertical bars represent the standard error of the means $(n=9)$. Means with different letters in the same crop are significant at $p<0.05$.

Table 3. Effects of additives on organic acids and ratio of LA/AA of silage

\begin{tabular}{clccccc}
\hline Crop & Treatment & pH & LA $(\mathbf{g} / \mathbf{k g})$ & AA $(\mathbf{g} / \mathbf{k g})$ & BA $(\mathbf{g} / \mathbf{k g})$ & LA $/ A A$ \\
\hline Proso & C & $4.35^{\mathrm{a}}$ & $40.08^{\mathrm{b}}$ & $14.14^{\mathrm{b}}$ & 2.27 & $2.83^{\mathrm{b}}$ \\
millet & FA & $4.24^{\mathrm{b}}$ & $21.02^{\mathrm{c}}$ & $35.91^{\mathrm{a}}$ & $\mathrm{ND}$ & $0.59^{\mathrm{c}}$ \\
& LP & $4.25^{\mathrm{b}}$ & $76.67^{\mathrm{a}}$ & $18.63^{\mathrm{ab}}$ & $\mathrm{ND}$ & $4.12^{\mathrm{a}}$ \\
& Mean & $4.28^{\mathrm{A}}$ & $45.92^{\mathrm{B}}$ & $22.89^{\mathrm{C}}$ & $0.76^{\mathrm{B}}$ & $2.51^{\mathrm{A}}$ \\
Corn & C & $3.86^{\mathrm{a}}$ & $61.45^{\mathrm{b}}$ & $48.60^{\mathrm{b}}$ & $\mathrm{ND}$ & $1.26^{\mathrm{b}}$ \\
& FA & $3.55^{\mathrm{b}}$ & $58.83^{\mathrm{b}}$ & $96.20^{\mathrm{a}}$ & $\mathrm{ND}$ & $0.61^{\mathrm{b}}$ \\
& LP & $3.53^{\mathrm{b}}$ & $70.42^{\mathrm{a}}$ & $24.37^{\mathrm{b}}$ & $\mathrm{ND}$ & $2.89^{\mathrm{a}}$ \\
& Mean & $3.65^{\mathrm{B}}$ & $63.57^{\mathrm{A}}$ & $56.39^{\mathrm{B}}$ & $\mathrm{ND}$ & $1.59^{\mathrm{B}}$ \\
SSH & C & $4.07^{\mathrm{a}}$ & $76.70^{\mathrm{a}}$ & $45.23^{\mathrm{b}}$ & $\mathrm{ND}$ & $1.70^{\mathrm{a}}$ \\
& FA & $3.62^{\mathrm{b}}$ & $32.61^{\mathrm{b}}$ & $97.81^{\mathrm{a}}$ & 5.91 & $0.33^{\mathrm{c}}$ \\
& LP & $3.70^{\mathrm{b}}$ & $78.37^{\mathrm{a}}$ & $80.70^{\mathrm{ab}}$ & $\mathrm{ND}$ & $0.97^{\mathrm{b}}$ \\
& Mean & $3.80^{\mathrm{B}}$ & $62.56^{\mathrm{A}}$ & $74.58^{\mathrm{A}}$ & $1.97^{\mathrm{A}}$ & $1.00^{\mathrm{B}}$ \\
\hline \multirow{2}{*}{$p$-value } & V & 0.0261 & $<0.0001$ & $<0.0001$ & 0.0370 & $<0.0001$ \\
& A & $<0.0001$ & $<0.0001$ & $<0.0001$ & 0.8913 & $<0.0001$ \\
& V $\times \mathrm{A}$ & $<0.0001$ & $<0.0001$ & $<0.0001$ & 0.0463 & $<0.0001$ \\
\hline
\end{tabular}

Different lowercase letters in the same column indicate significant differences among additives $(p<0.05)$ and different uppercase letters in the same column indicate significant differences among crops $(p<0.05)$.

LA, lactic acid; AA, acetic acid; BA, butyric acid; C, control; FA, formic acid; ND, not detected; LP, Lactobacillus plantarum; SSH, sorghum-sudangrass hybrid; $V$, variety; $A$, additive.

AA). For the three crops, the LP treatment gave the highest lactic acid concentration, followed by the control and FA $(p<0.05)$. The lactic acid contents of the three LP-treated crop silages showed little difference (i.e., proso millet, $76.67 \mathrm{~g} / \mathrm{kg}$; corn, $70.42 \mathrm{~g} / \mathrm{kg}$; SSH hybrid, $78.37 \mathrm{~g} / \mathrm{kg}$ ). As can be seen from Table 3, among the treatments of the three crops, the FA treatment group had the highest acetic acid content, which was significantly higher than those of the control group and the LP treatment group $(p<0.05)$. The SSH had the highest content of acetic acid, followed by corn and proso millet. In all treatments, butyric acid was only detected in the control of millet and the FA treatment of SSH $(2.27$ and $5.91 \mathrm{~g} / \mathrm{kg}$, respectively). 
In our study, the highest LA/AA ratio was observed for the LP-treated silage of proso millet (4.12). Similarly, the LA/AA ratio of the LP treatment group was also higher for corn and SSH. By contrast, in the treatments of the three crops, the LA/AA ratio of the FA treatment group was significantly lower than those of the control group and the LP treatment group $(p<0.05)$.

\section{Microbial counts of silages treated with different additives}

As shown in Table 4, we found that the additives had a significant effect on the numbers of silage microorganisms $(p<0.05)$. Although here were no differences between crops, LAB counts were highest in the silages treated with the LP additive. The FA-treated silages had fewer LAB than either the control or the LP-treated silages. In all FA treatment groups, the total microorganism and mold numbers were significantly lower than those of the control and LP groups $(p<0.05)$. The numbers of LAB and total microorganisms did not differ significantly among the species. The corn silage had significantly lower mold than the proso millet and SSH silages $(p<0.05)$.

\section{DISCUSSION}

It has been reported that an initial WSC content between 60 and $80 \mathrm{~g} / \mathrm{kg}$ DM is sufficient to produce high-quality silage [20]. Thus, all forage crops in this study contained sufficient WSC (136.7-170.0 g/kg) for fermentation into good-quality silage. Chemical changes are inevitable during ensiling due to the conversion of soluble carbohydrates into organic acids and the degradation of fresh crop fibers and proteins. For the proso millet and SSH, the DM contents in the groups with additives were higher than that of the control group. Correspondingly, the DM losses of the proso millet and SSH with additives groups were lower than that of the control group [21]. The use of FA as an additive can effectively restrict the fermentation of silage, thereby reducing the loss of DM [22]. The addition of LP to silage can produce a large amount of lactic acid, which

Table 4. Microbial compositions of silages after 60 days of ensiling

\begin{tabular}{|c|c|c|c|c|}
\hline Crop & Treatment & $\begin{array}{c}\text { LAB } \\
\left(\log _{10} \text { CFU/g FW) }\right.\end{array}$ & $\begin{array}{c}\text { Mold } \\
\left(\log _{10} \text { CFU /g FW) }\right. \\
\end{array}$ & $\begin{array}{c}\text { TM } \\
\left(\log _{10} \text { CFU /g FW) }\right.\end{array}$ \\
\hline \multirow[t]{4}{*}{ Proso millet } & $C$ & $5.12^{b}$ & $4.15^{\mathrm{a}}$ & $6.55^{\mathrm{b}}$ \\
\hline & FA & $5.00^{b}$ & $3.70^{\mathrm{b}}$ & $6.08^{c}$ \\
\hline & LP & $6.82^{\mathrm{a}}$ & $3.98^{\mathrm{ab}}$ & $7.26^{\mathrm{a}}$ \\
\hline & Mean & $5.65^{\mathrm{C}}$ & $3.94^{\mathrm{A}}$ & $6.63^{\mathrm{B}}$ \\
\hline \multirow[t]{4}{*}{ Corn } & C & $6.15^{\mathrm{b}}$ & $3.16^{\mathrm{a}}$ & $7.10^{\mathrm{b}}$ \\
\hline & FA & $5.54^{\mathrm{c}}$ & $3.05^{\mathrm{b}}$ & $6.89^{\mathrm{b}}$ \\
\hline & LP & $7.20^{\mathrm{a}}$ & $3.01^{\mathrm{b}}$ & $7.70^{\mathrm{a}}$ \\
\hline & Mean & $6.30^{\mathrm{A}}$ & $3.07^{\mathrm{B}}$ & $7.23^{\mathrm{A}}$ \\
\hline \multirow[t]{4}{*}{ SSH } & C & $5.88^{\mathrm{b}}$ & $4.28^{\mathrm{a}}$ & $6.35^{\mathrm{c}}$ \\
\hline & FA & $5.12^{c}$ & $3.08^{c}$ & $6.75^{\mathrm{b}}$ \\
\hline & LP & $7.14^{\mathrm{a}}$ & $3.30^{\mathrm{b}}$ & $7.35^{\mathrm{a}}$ \\
\hline & Mean & $6.05^{\mathrm{B}}$ & $3.55^{\mathrm{AB}}$ & $6.82^{\mathrm{B}}$ \\
\hline \multirow[t]{3}{*}{$p$-value } & V & $<0.0001$ & 0.0407 & $<0.0001$ \\
\hline & $A$ & $<0.0001$ & $<0.0001$ & $<0.0001$ \\
\hline & $V \times A$ & $<0.0001$ & $<0.0001$ & $<0.0001$ \\
\hline
\end{tabular}

Different lowercase letters in the same column indicate significant differences among additives $(p<0.05)$ and different uppercase letters in the same column indicate significant differences among crops $(p<0.05)$.

LAB, lactic acid bacteria; TM, total microorganisms; CFU, colony forming unit; FW, fresh weight; C, control; FA, formic acid; LP, Lactobacillus plantarum; SSH, sorghum-sudangrass hybrid; V, variety; A, additive. 
can reduce the $\mathrm{pH}$ of the silage in a short time, effectively inhibiting the growth of undesired microorganisms and also reducing DM losses [23]. Thus, in most experiments, the addition of FA should inhibit the growth of undesirable microorganisms and also reduce losses. However, Rooke et al. [24] showed that silage after the addition of FA cannot completely inhibit the growth of yeast that can consume WSC in the silage, accompanying the loss of DM, which is consistent with our experimental data for corn.

The additive treatments of the three silage crops had higher $\mathrm{CP}$ contents than the control groups. The highest $\mathrm{CP}$ content was detected in the LP-treated groups which can be explained by the fact that the LP application induced rapid acidification, thereby suppressing protein degradation by undesired microorganisms [25]. The FA treatments also showed enhanced preservation of $\mathrm{CP}$ content. This may be due to the restriction of fermentation, deamination, and decarboxylation of proteins after the addition of FA $[24,26]$. The proso millet treated with additives had significantly decreased contents of NDF and ADF compared with the control group $(p<0.05)$. This conclusion is the same as the conclusion of Baytok et al. [27]. The NDF and ADF contents of the SSH treated with additives decreased slightly. When LP is added to silage, LAB can effectively degrade the composition of the cell wall, thereby reducing the fiber content [8]. Desta et al. [28] reported that the addition of FA directly reduces the $\mathrm{pH}$ value by quickly acidifying raw materials, which significantly reduces the contents of cellulose and hemicellulose in grass silage. The NDF in the corn control group was significantly lower than that in the additive groups $(p<0.05)$, but the ADF content did not differ significantly. This may have occurred because the additive treatment inhibited the activity of plant enzymes and reduced degradation of the cell wall. The IVDMD increased with the addition of additives, possibly because the use of additives significantly improves the quality of silage fermentation, inhibits unfavorable microbial fermentation, and especially inhibits protein digestion and hydrolysis, thereby increasing the IVDMD [29]. Li et al. [30] also found that treatments with organic acid could increase the IVDMD.

In the process of ensiling, microbial fermentation produces organic acids, causing the $\mathrm{pH}$ of the silage to decrease. Adding FA as an acid to silage directly reduces the $\mathrm{pH}$ of the silage, whereas adding $\mathrm{LP}$ increases the number of LAB, which then produce more lactic acid and thus lower the $\mathrm{pH}$. This finding has been verified in other studies [31]. WSCs are considered to be important substrates for LAB growth during proper fermentation, and WSC is consumed continuously as fermentation proceeds. As in our study, treatment of silage with FA additives results in increased residual WSC concentration, indicating that partial inhibition of fermentation results in WSC not being consumed continuously. In comparison with the control group, the WSC content of the LP treatment was also higher. This may have occurred because the large amount of LAB consumed WSC while reducing the $\mathrm{pH}$ of the silage, thus inhibiting the growth of undesirable microorganisms and thereby reducing their consumption of WSC. This also indicates that the LPtreated group reached a steady state quickly, allowing a portion of the WSC to be retained. Meeske et al. [32] also reported that bacterial additives have no effect on WSC during fermentation, which indicates that WSC has the same utilization rate in control and LP-treated silage. Protein hydrolysis in silage leads to an increase in soluble $\mathrm{N}$ and $\mathrm{NH}_{3}-\mathrm{N}$ during ensiling [33]. Wellpreserved silages should contain less than $100 \mathrm{~g} \mathrm{NH}_{3}-\mathrm{N} / \mathrm{kg}$ TN [6]. As can be seen from Fig. 3, except for the control and FA-treated silage of proso millet, the remaining treatments met the requirements of well-preserved silage $(18.97-81.83 \mathrm{~g} / \mathrm{kg})$. For the three crops, the $\mathrm{NH}_{3}-\mathrm{N} / \mathrm{TN}$ contents of the additive-treated groups were much lower than those of the control groups. This is consistent with the conclusion of Contreras-Govea et al. [34]. The lower $\mathrm{NH}_{3}-\mathrm{N} / \mathrm{TN}$ in the silage indicated inhibition of proteolysis during fermentation, and therefore the efficiency of nitrogen synthesis by rumen microorganisms was improved [35]. 
In all of the crops, use of the LP additive increased the concentration of lactic acid compared to the control group. It may be that the lactic acid acidification in the LP silages was enhanced by the addition of exogenous LP, which favored homo-fermentation of silage and thus resulted in higher production of lactic acid [36]. Contreras-Govea et al. [34] also found that inoculant containing LP increased the concentration of lactic acid in maize silage. Many reports have indicated that addition of FA to silage limits the fermentation of silage, thereby reducing the content of lactic acid in the silage [37,38]. This conclusion is consistent with our experimental data. As can be seen from Table 3 , the use of FA can increase the content of acetic acid in silage. This result shows that the addition of organic acid can provide a favorable environment for the growth of hetero-fermentation bacteria and thus more acetic acid. The same results were observed during ensiling of maize after the addition of FA [38]. The highest content of acetic acid occurred in the SSH, possibly because the $\mathrm{BC}$ value of the sorghum-sudangrass was higher, which prolonged the fermentation time, resulting in a large amount of acetic acid production. Butyric acid is produced by clostridia, and its presence is related to the degree of silage spoilage. For proso millet, its presence may have occurred because the activity of clostridia in the untreated silage was not restricted. The presence of butyric acid in the SSH may have been due to the high moisture content of the SSH, which creates an environment suitable for the growth of clostridia and thus leads to the production of butyric acid. This is in agreement with the result that clostridial fermentation occurs particularly when an ensiled crop has low WSC and DM contents at high temperature [39]. As Jones et al. [40] demonstrated, the LA/ AA ratio is an efficiency indicator of homo- or hetero-fermentation. In our study, the highest value of $4.12(p<0.05)$ was observed in the LP-treated silage of proso millet. This indicates that the LP additive used made the fermentation more homo-fermentative.

The FA-treated silages had fewer LAB than either the control or LP-treated silages. The same result was found by Da Silva et al. [41] and Tyrolová et al. [38]. With addition of FA, the total number of microorganisms and the number of molds were relatively reduced. This occurred because FA treatment can inhibit the growth of undesirable microorganisms. The mold content of forage crops is one of the factors affecting their fermentation quality. Molds are aerobic microorganisms present in silage that can cause spoilage during ensiling [42]. Among all treatments, the corn groups had the lowest amounts of mold, possibly because the low $\mathrm{pH}$ of the corn silage effectively inhibited the growth of undesirable microorganisms.

\section{CONCLUSION}

In conclusion, both additives improved the fermentation quality and nutritional composition of the main summer forage crops. Latic acid inoculant increased lactic acid content and LA/AA ratio. FA inhibited the fermentation of crops. The FA inhibited the silage fermentation. Thus, the lactic acid content was reduced and the acetic acid content was increased, and the average $\mathrm{pH}$ was the lowest at 3.80. Proso millet is a cash crop, and its potential for forage is sufficient; however, use of additives to improve silage quality is recommended.

\section{REFERENCES}

1. Kim DA. Forage crops: its characteristics and cultivation methods. Seoul: Seonjinmunhwasa; 1991.

2. Sarrantonio M. Northeast cover crop handbook. Emmaus, PA: Rodale Institute; 1994.

3. Valenzuela H, Smith J. Sorghum-sudangrass hybrids (Green Manure Crops). Honolulu, HI: University of Hawaii at Manoa; 2020. Report No.: SA-GM-10. 2002. 
4. Kumar KA, Adrews DJ. Genetics of qualitative traits in pearl millet: a review. Crop Sci. 1993;33:1-20. https://doi.org/10.2135/cropsci1993.0011183X003300010001x

5. Kim JH, Park HS, Cho JW. Comparison of forage yields and growth of summer forage sorghum, proso millet and Japanese millet according to cropping system with winter forage barley. J Korean Soc Grassl Forage Sci. 2018;38:286-90. https://doi.org/10.5333/KGFS.2018.38.4.286

6. McDonald P, Henderson AR, Heron SJE. The biochemistry of silage. 2nd ed. Marlow, UK: Chalcombe; 1991.

7. Kung L, Muck R. Animal response to silage additives. Paper presented at the Proceedings of the Conference on Silage: Field to Feedbunk, North American Conference; 1997 Feb 11-13; Hershey, PA.

8. Tao Z. Screening of alfalfa (Medicago sativa L.) silage agents, mechanism of action and application research. Beijing: China Agricultural University; 2005.

9. Wilson RF, Wilkins RJ. Formic acid as a silage additive for wet crops of cocksfoot and lucerne. J Agric Sci. 1973;80:225-31. https://doi.org/10.1017/S0021859600057671

10. Silveira AC, Tosi H, De Faria, V, Spers A. Efeito de diferentes tratamentos na digestibilidade in vitro de silagens de capim Napier. Rev Da Soc Bras Zootec. 1973;2:216-26.

11. Jean-Baptiste-André Dumas. Science. 1884;3:750-2. https://doi.org/10.1126/science.ns3.72 .750

12. Van Soest PJ, Robertson JB Lewis BA. Methods for dietary fiber, neutral detergent fiber, and nonstarch polysaccharides in relation to animal nutrition. J Dairy Sci. 1991;74:3583-97. https:// doi.org/10.3168/jds.S0022-0302(91)78551-2

13. Yemm EW, Willis AJ. The estimation of carbohydrates in plant extracts by anthrone. Biochem J. 1954;57:508-14. https://doi.org/10.1042/bj0570508

14. Holland C, Kezar W, Kautz WP, Lazowski EJ, Mahanna WC, Reinhart R. The pioneer forage manual: a nutritional guide. Desmoines, IA: Pioneer Hi-Bred International; 1990. p. 1-55.

15. Tilley JMA. Terry RA. A two-stage technique for the in vitro digestion of forage crops. J Brit Grassl Soc. 1963;18:104-11. https://doi.org/10.1111/j.1365-2494.1963.tb00335.x

16. Madigan MT. Brock biology of microorganisms. Boston, MA: Pearson; 2012.

17. Podkowka W. Modern methods of ensiling. Warszawa, Poland: PWRiL; 1978.

18. Playne MJ, McDonald P. The buffering constituents of herbage and of silage. J Sci Food Agric. 1966;17:264-8. https://doi.org/10.1002/jsfa.2740170609

19. Broderick GA, Kang JH. Automated simultaneous determination of ammonia and total amino acids in ruminal fluid and in vitro media. J Dairy Sci. 1980;63:64-75. https://doi.org/10.3168/ jds.S0022-0302(80)82888-8

20. Amer S, Hassanat F, Berthiaume R, Seguin P, Mustafa AF. Effects of water soluble carbohydrate content on ensiling characteristics, chemical composition and in vitro gas production of forage millet and forage sorghum silages. Anim Feed Sci Technol. 2012;177:23-9. https://doi. org/10.1016/j.anifeedsci.2012.07.024

21. Henderson N. Silage additives. Anim Feed Sci Technol. 1993;45:35-56. https://doi. org/10.1016/0377-8401(93)90070-Z

22. Rowghani E, Zamiri MJ. The effects of a microbial inoculant and formic acid as silage additives on chemical composition, ruminal degradability and nutrient digestibility of corn silage in sheep. Iranian J Vet Res. 2009;10:110-18.

23. Weinberg ZG, Ashbell G, Hen Y, Azrieli A, Szakacs G, Filya I. Ensiling whole-crop wheat and corn in large containers with Lactobacillus plantarum and Lactobacillus buchneri. J Ind Microbiol Biotechnol. 2002;28:7-11. https://doi.org/10.1038/sj/jim/7000207

24. Rooke JA, Maya FM, Arnold JA, Armstrong DG. The chemical composition and nutritive 
value of grass silages prepared with no additive or with the application of additives containing either Lactobacillus plantarum or formic acid. Grass Forage Sci. 1988;43:87-95. https://doi. org/10.1111/j.1365-2494.1988.tb02144.x

25. Zhao J, Dong Z, Li J, Chen L, Bai Y, Jia Y, et al. Effects of lactic acid bacteria and molasses on fermentation dynamics, structural and nonstructural carbohydrate composition and in vitro ruminal fermentation of rice straw silage. Asian-Australas J Anim Sci. 2019;32:783-91. https:// doi.org/10.5713/ajas.18.0543

26. Chamberlain D, Martin P, Robertson S. The effectiveness of the extent of fermentation in the silo on the nutritional value of grass silage for milk production. Proceedings of the 9th Silage Conference; 1990 DEC 1; Newcastle, UK.

27. Baytok E, Aksu T, Karsli MA, Muruz H. The effects of formic acid, molasses and inoculant as silage additives on corn silage composition and ruminal fermentation characteristics in sheep. Turk J Vet Anim Sci. 2005;29:469-74.

28. Desta ST, Yuan X, Li J, Shao T. Ensiling characteristics, structural and nonstructural carbohydrate composition and enzymatic digestibility of Napier grass ensiled with additives. Bioresour Technol. 2016;221:447-54. https://doi.org/10.1016/j.biortech.2016.09.068

29. Fililya İ.The effects of lactic acid bacterial inoculants on the fermentation, aerobic stability and in situ rumen degradability characteristics of maize and sorghum silages. Turk J Vet Anim Sci. 2002;26:815-23.

30. Li P,Ji S, Hou C, Tang H, Wang Q, Shen Y. Effects of chemical additives on the fermentation quality and N distribution of alfalfa silage in south of China. Anim Sci J. 2016;87:1472-9. https://doi.org/10.1111/asj.12600

31. Zhang Q, Yu Z, Na RS. Effects of different additives on fermentation quality and aerobic stability of Leymus chinensis silage. Grass Forage Sci. 2018;73:413-9. https://doi.org/10.1111/ gfs.12301

32. Meeske R, Van der Merwe G, Greyling JF, Cruywagen CW. The effect of the addition of a lactic acid bacterial inoculant to maize at ensiling on silage composition, silage intake, milk production and milk composition. S Afr J Anim Sci. 2002;32:263-70.

33. Kung L, Shaver RD, Grant RJ, Schmidt RJ. Silage review: interpretation of chemical, microbial, and organoleptic components of silages. J Dairy Sci. 2018;101:4020-33. https://doi. org/10.3168/jds.2017-13909

34. Contreras-Govea FE, Muck RE, Broderick GA, Weimer PJ. Lactobacillus plantarum effects on silage fermentation and in vitro microbial yield. Anim Feed Sci Technol. 2013;179:61-8. https://doi.org/10.1016/j.anifeedsci.2012.11.008

35. Nsereko VL, Rooke JA. Effects of peptidase inhibitors and other additives on fermentation and nitrogen distribution in perennial ryegrass silage.J Sci Food Agric. 1999;79:679-86. https://doi. org/10.1002/(SICI)1097-0010(199904)79:5<679::AID-JSFA235>3.0.CO;2-3

36. Adesogan AT, Salawu MB. The effect of different additives on the fermentation quality, aerobic stability and in vitro digestibility of pea/wheat bi-crop silages containing contrasting pea to wheat ratios. Grass Forage Sci. 2002;57:25-32. https://doi.org/10.1046/j.13652494.2002.00298.x

37. Kennedy SJ. Comparison of the fermentation quality and nutritive value of sulphuric and formic acid-treated silages fed to beef cattle. Grass Forage Sci. 1990;45:17-28. https://doi. org/10.1111/j.1365-2494.1990.tb02178.x

38. Tyrolová $\mathrm{Y}$, Bartoň L, Loučka R. Effects of biological and chemical additives on fermentation progress in maize silage. Czech J Anim Sci. 2017;62:306-12. https://doi. org/10.17221/67/2016-CJAS 
39. Oladosu Y, Rafii MY, Abdullah N, Magaji U, Hussin G, Ramli A, et al. Fermentation quality and additives: a case of rice straw silage. BioMed Res Int. 2016;1-14. https://doi. org/10.1155/2016/7985167

40. Jones BA, Satter LD, Muck RE. Influence of bacterial inoculant and substrate addition to lucerne ensiled at different dry matter contents. Grass Forage Sci. 1992;47:19-27. https://doi. org/10.1111/j.1365-2494.1992.tb02243.x

41. Da Silva TC, Smith ML, Barnard AM, Kung L. The effect of a chemical additive on the fermentation and aerobic stability of high-moisture corn. J Dairy Sci. 2015;98:8904-12. https:// doi.org/10.3168/jds.2015-9640

42. Muck RE. Silage microbiology and its control through additives. R Brasi Zootec. 2010;39:18391. https://doi.org/10.1590/S1516-35982010001300021 